\title{
MODEL OF HUMAN RESOURCE PERFORMANCE IMPROVEMENT BASED ON HUMAN CAPITAL AND SOCIAL CAPITAL WITH THE MODERATION OF INFORMATION TECHNOLOGY
}

\author{
Budiarti Ningrum*
}

* Affiliation:
${ }^{1}$ Balai Monitoring SFR
Kelas I, Semarang,
Indonesia
email:
ningrummail@ gmail.com

ningrummail@gmail.com

\begin{abstract}
:
This study investigates the effect of human capital and social capital on human resource performance, and the moderating effect of information technology. Based on a total sample of 88 respondents from the Technical Implementation Unit (UPT) of Monitor Radio Frequency Spectrum Class I Semarang and Yogyakarta which is analyzed using structural equation modeling based smartPLS 3.0, the results indicated that 1) human capital is positively related to social capital and human resorce performance; 2) social capital is positively related to human resorce performance; 3) information technology moderates the relationships between social capital and human resorce performance; and 4) information technology moderates the relationships between human capital and human resource performance.
\end{abstract}

Keywords: Human capital, Social capital, Information technology, Human resource performance

\section{INTRODUCTION}

The development of telecommunications technology at the international level, followed by an increase in its use as one of the trading commodities, which has high commercial value, has led to various multilateral agreements. In accordance with the principle of global trade, which focuses on the principle of free trade and nondiscrimination, Indonesia must prepare to adjust telecommunications operations.

Control of the radio frequency spectrum is the responsibility of the Technical Implementation Unit (UPT) of the Directorate General of Resources and Equipment of Post and Information Technology which is domiciled in the capital of each province in Indonesia with different areas and characteristics of the community. The existence of these institutions is intended so that frequency used can be regulated and run in an orderly manner according to its designation. Besides that, 
the institution can take direct action in the event of violation or misuse of frequency, such as illegal or unauthorized frequency usage so that it will cause interference to other frequency users.

In the framework of the main tasks and functions in frequency monitoring and control, the Technical Implementation Unit (UPT) of Monitor Radio Frequency Spectrum requires human

resources that are competent in their field so that excellent service quality can be achieved. However, human resources with the competencies needed are still lacking so that they are not optimal in carrying out work, there are still violations in the field including illegal frequency usage even though it has been enforced even to court, frequency disturbances, warehousing of

devices that have not been used but not reported so that costs rights of use (BHP) of the frequency get late penalties while the user feels disadvantaged. Thus social capital becomes less optimal besides the lack of human capital needed to solve frequency usage problems.

Based on research gap, the study of Fonti and Maoret (2016); Islam et al. (2018); Liu (2017); Subramony et al. (2018) states social capital improves employee performance. But it is not in line with the study of Augusto Felício et al. (2014); McDowell et al. (2018) which concluded that social capital does not have a significant effect on performance. Therefore the research question in this study is "How to improve the performance of human resources based on human capital and social capital with the moderation of information technology"

\section{LITERATURE REVIEW Social Capital}

More comprehensively, Burt (2009) defines Social capital as the ability of people to associate each other and then become a very important force not only for economic life but also for every aspect of other social existence. Whereas Putnam (2012) defines Social Capital as a kind of social glue that facilitates action at the community level which, in turn, enables various benefits for community social activities. Fukuyama (1995) defines Social Capital as a series of informal values or norms that are shared among members of a group that enables cooperation between them. In line with Fukuyama, Cox E. (1997), Social Capital is relationships that are created and norms that shape the quality and quantity of social relations in society in a broad spectrum, namely as the social glue that maintains the unity of group members together. On the same path, Solow (1999) defines Social Capital as a set of values or norms embodied in behavior that can encourage the ability and capability to cooperate and coordinate to produce a major contribution to the sustainability of productivity.

Social capital is a trust-based relationship inherent in social networks (Baker et al., 2006; Carole, 2007), in research of Lee et al (2007) in leading companies in Taiwan also treated as a moderating relationship between entrepreneurial orientation and company performance. Entrepreneurs who use Social Capital in greater numbers will achieve better results for their company, both in terms of innovation, increased competence, and organizational effectiveness.

\section{Human Capital}

The human element is a potential influence on the success of the organization, in fact, now organizations that want to compete and survive must pay attention to their human resources as a driver of competitive advantage in business. Human Capital capabilities in 
applying knowledge into their work that makes a company have an advantage in competing.

Hawlett (2002) in his research on the integration of the concept of Human Capital in productivity and growth which refers to the concept of Theodore Schultz (1961), it is stated that investment in Human Capital is classified into several categories including Schools and higher education, job training, Migration, Health, and economic information

Becker (1984) states that the performance of dramatic economic progress achieved by Japan, Taiwan, and other Asian countries in the past decade illustrates the importance of human capital in growth. Although capital / natural resources are poor and discriminated against by Western countries, because of high investment in human capital they have achieved very rapid growth performance, which has been dubbed the Asian Tigers. Excellence in innovative and productive human resources is achieved through increased investment in the field of education that enables the accumulation of knowledge, so as to improve performance. Therefore the first hypothesis proposed in this study is:

\section{H1 : The higher human capital, the performance of human resources increases}

The researchers say that individual external social ties provide access to important resources for the company (Brown \& Duguid, 1998). Human capital is seen as an antecedent of network resources because it represents the capability of the organization to effectively respond to the needs of external partners, solve their various problems and various kinds of information. Therefore the hypothesis proposed is:

\section{H2: The higher the human capital, the social capital increases}

\section{H3: The higher the social capital, the better the performance of human resources}

\section{Information Technology}

Information technology is the use of computers to store, retrieve, send, and manipulate data or information, which is often used in a business or organizational context. Bharadwaj (2000) defines information technology as the ability of organizations to acquire, disseminate and utilize information technology resources in combining with other resources to achieve organizational goals. Whereas Kmieciak et al. (2012) belived that information technology as one of the main organizational capabilities that can contribute to innovation and superior performance.

Information technology has become a strategic resource that is very important for the organization. Information technology provides a concentration of information that is important for good decision making (Galbraith, 2012). The categorization of success in information technology in the organization includes six main dimensions, namely the quality of information technology, information quality, use of information technology, customer (employee) satisfaction, individual influence and organizational influence. The importance of information technology infrastructure has had a huge influence on flexibility, competitive advantage and organizational performance (Gheysari et al., 2012).

Information technology is very closely related to users or employees in the organization. Managers must be aware of the importance of information technology acceptance on the part of 
employees as a way to realize the benefits of information technology, as well as improvements in organizational performance as a whole (Mitić et al., 2017). The results of the study of Wadhwa et al. (2017) prove that human capital and social capital encourage the improvement of information technology, which in turn influences employee performance.

H4: Information technology moderates the relationship between social capital and human resources performance

H5: Information technology moderates the relationship between human capital and the human resources performance

Based on a comprehensive and in-depth literature review, the empirical model of this study can be presented in Figure 1 below.

\section{Figure 1. Empirical Model}

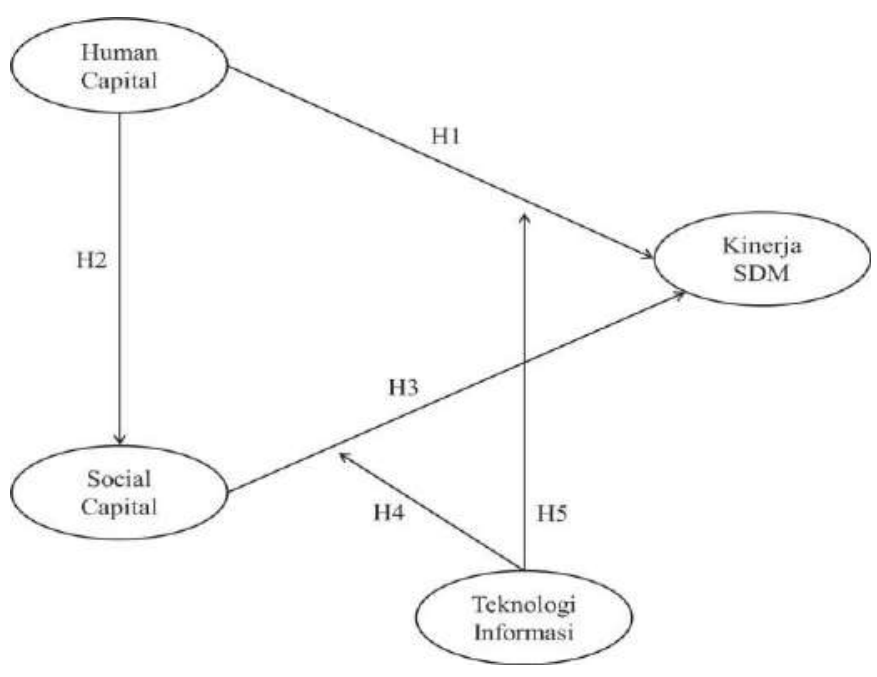

\section{METHODS}

The population in the study is human resources are employees of the Frequency Spectrum Technical Implementation Unit (UPT). Because the research uses the census method, the study respondents were as many as 80 people by taking samples at 2 Technical Implementation Units (UPTs) of Monitor Radio Frequency Spectrum Class I Semarang and Yogyakarta.

Data collection techniques were carried out using questionnaires, interviews and field observations. This type of data was obtained directly from the distribution of questionnaires to Technical Implementation Units (UPTs) of Monitor Radio Frequency Spectrum Class I. While secondary data in this study were obtained from annual report data and documentation. 


\section{RESULT}

Table 1 Description of Respondents

\begin{tabular}{|c|c|c|c|c|}
\hline No. & Item & Description & Frequency & Percentage (\%) \\
\hline \multirow[t]{2}{*}{1} & Sex & Male & 56 & 70 \\
\hline & & Female & 24 & 30 \\
\hline \multirow[t]{4}{*}{2} & Age & $<30$ y.o & - & - \\
\hline & & 30 s/d 39 y.o & - & - \\
\hline & & 40 s/d 49 y.o & 2 & 2,5 \\
\hline & & $>50$ y.o & 78 & 97,5 \\
\hline \multirow[t]{3}{*}{3} & Education Level & Diploma & 31 & 38,75 \\
\hline & & Undergraduate & 36 & 45 \\
\hline & & Post Graduate & 13 & 16,25 \\
\hline \multirow[t]{4}{*}{4} & Length of Working Time & $3 \mathrm{~s} / \mathrm{d} 5$ years & 3 & 3,75 \\
\hline & & $6 \mathrm{~s} / \mathrm{d} 8$ years & 15 & 18,75 \\
\hline & & $9 \mathrm{~s} / \mathrm{d} 11$ years & 16 & 20 \\
\hline & & $>12$ years & 46 & 57,5 \\
\hline
\end{tabular}

Source: Primary Data Processed (2018)

Based on Table 1 shows that from the 80 respondents involved in the study, the majority were 56 male (70\%), and were only 24 woman (30\%). This shows that the majority of employees at the Technical Implementation Units (UPTs) of Monitor Radio Frequency Spectrum Class I Semarang and Yogyakarta who were respondents in this study were male, meaning that the existing work in the Technical Implementation Units (UPTs) of Radio Frequency was preferred and chosen by men rather than women.

Table 1 also shows that respondents who participated in the study, the majority were aged over 36 years as many as 78 people (97.5\%). While respondents aged between 31 to 35 years were 2 people $(2.5 \%)$, and there were no respondents under the age of 30 years. This shows that the majority of employees in Technical Implementation Units (UPTs) of Monitor Radio Frequency Spectrum Class I Semarang and Yogyakarta who became respondents in this study were over 36 years old, meaning that this age was considered mature in realizing organizational performance as a whole.

Table 1 also shows that the respondents who participated in the study, the majority were undergraduate education level as many as 36 people (45\%). While Diploma graduates were 31 people $(38.75 \%)$, and post graduate education level were 13 people $(16.25 \%)$. This shows that most of the employees in the Technical Implementation Units (UPTs) of Monitor Radio Frequency Spectrum Class I Semarang and Yogyakarta who became respondents in this study were undergraduate education level. This indicates that the level of S-1 education is considered to be very feasible to start and do work within the organization.

Table 1 also shows that respondents who participated in the study, the majority were those who had a service period of more than 12 years as many as 46 people (57.5\%). While employees 
who have a working period of 9 to 11 years are 16 people (20\%), who have a working period of 6 to 8 years as many as 15 people (18.75\%), and who have a working period between 3 and 5 years as many as 3 people $(3.75 \%)$. This shows that the majority of employees in the Technical Implementation Units (UPTs) of Monitor Radio Frequency Spectrum Class I who became respondents in this study were employees with a service period of more than 12 years. This indicates that with a sufficient working period, employees are able to show the best performance.

\section{Validity and Realibility Test}

Based on the test results using SmartPLS 3 in Table 2 and Table 3, it is known that all indicators in the variables of Human Capital, Social Capital, and Human Resource Performance have a loading factor above 0.5 and all constructs are above 0.7 . This means that all variable indicators in this study are said to be valid and reliable so that they can be used in research.

Table 2 Outer Loadings

\begin{tabular}{|l|c|c|c|}
\hline & Human Capital & HR Performance & Social Capital \\
\hline HC1 & 0,844015 & & \\
\hline HC2 & 0,807237 & & \\
\hline HC3 & 0,612723 & & \\
\hline KK1 & & 0,725340 & \\
\hline KK2 & & 0,784138 & \\
\hline KK3 & & 0,592826 & \\
\hline KK4 & & 0,525836 & \\
\hline SC1 & & & 0,724676 \\
\hline SC2 & & & 0,604563 \\
\hline SC3 & & & 0,820687 \\
\hline
\end{tabular}

Source: Primary Data Process, 2018

Table 3 Composite Reliability

\begin{tabular}{cc}
\hline & Composite Reliability \\
\hline Human Capital & 0,802608 \\
HR Performance & 0,755853 \\
Social Capital & 0,762988 \\
\hline
\end{tabular}

Source: Primary Data Process, 2018

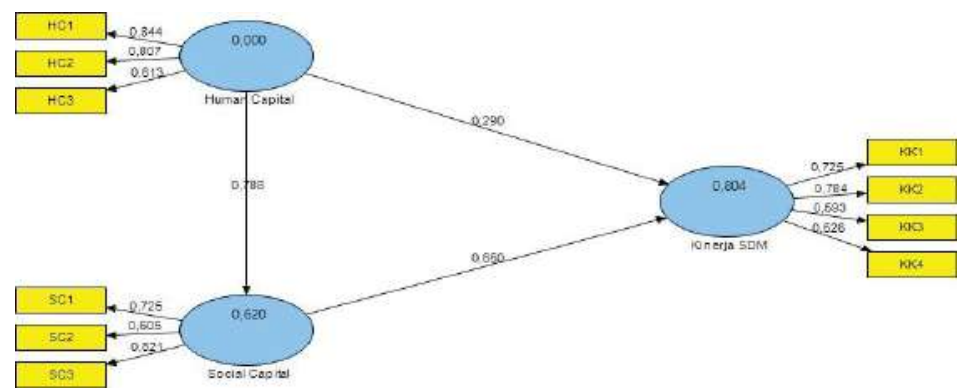

Figure 2 Structural Models Before Moderation 


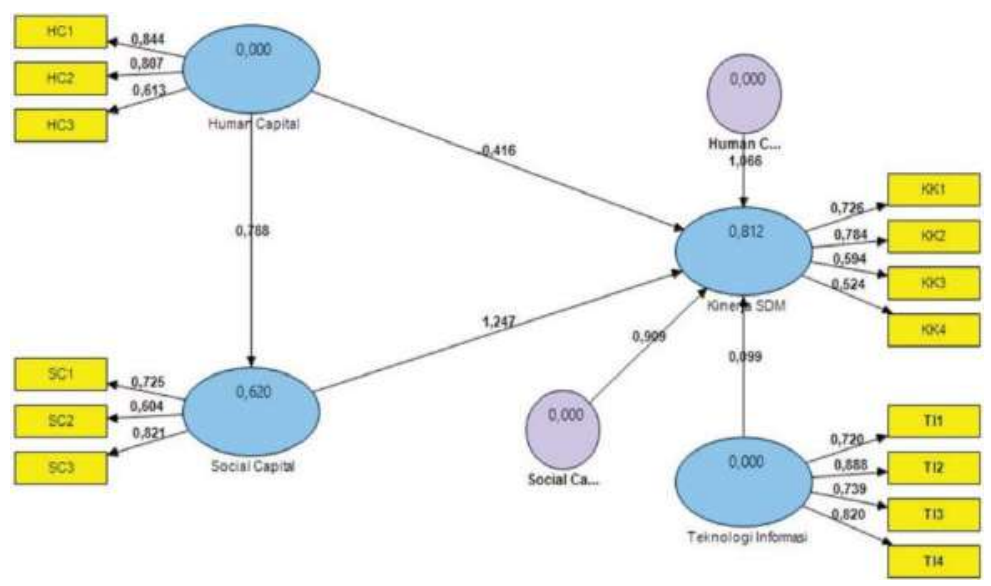

Figure 3 Structural Models After Moderation

Table 4 R-Square

\begin{tabular}{ccc} 
& R Square \\
\hline Human Capital & \\
HR Performance & 0,803601 \\
Social Capital & 0,620500 \\
\hline
\end{tabular}

Source: Primary Data Process, 2018

Based on Table 4 shows the R-square value of the Social Capital construct of 0.6205 which means that Human Capital is able to explain Social Capital variance of $62.05 \%$ and the rest $(37.95 \%)$ is influenced by other factors not examined in this study. Furthermore, the R-square value is also found in the construct of HR Performance which is equal to 0.8036, which means that Human Capital and Social Capital are able to explain the variance of HR Performance by $80.36 \%$ and the rest $(19.64 \%)$ is influenced by other factors not examined in this research.

Table 5 Path Coefficients Before Moderation

\begin{tabular}{|l|c|c|c|c|c|}
\hline & $\begin{array}{c}\text { Original } \\
\text { Sample }\end{array}$ & $\begin{array}{c}\text { Mean of } \\
\text { Sample }\end{array}$ & $\begin{array}{c}\text { Standard } \\
\text { Deviation }\end{array}$ & $\begin{array}{c}\text { Standard } \\
\text { Error }\end{array}$ & $\begin{array}{c}\text { T } \\
\text { Statistics }\end{array}$ \\
\hline $\begin{array}{l}\text { Human Capital } \rightarrow \text { HR } \\
\text { Performance }\end{array}$ & 0,289865 & 0,291409 & 0,094977 & 0,094977 & 3,051936 \\
\hline $\begin{array}{l}\text { Human Capital } \rightarrow \text { Social } \\
\text { Capital }\end{array}$ & 0,787718 & 0,805016 & 0,027149 & 0,027149 & 29,014131 \\
\hline $\begin{array}{l}\text { Social Capital } \rightarrow \text { HR } \\
\text { Performance }\end{array}$ & 0,650141 & 0,653353 & 0,083771 & 0,083771 & 7,760937 \\
\hline
\end{tabular}

Source: Primary Data Process, 2018 
Table 6 Path Coefficients After Moderation

\begin{tabular}{|l|c|c|c|c|c|}
\hline & $\begin{array}{c}\text { Original } \\
\text { Sample }\end{array}$ & $\begin{array}{c}\text { Mean of } \\
\text { Sample }\end{array}$ & $\begin{array}{c}\text { Standard } \\
\text { Deviation }\end{array}$ & $\begin{array}{c}\text { Standard } \\
\text { Error }\end{array}$ & T Statistics \\
\hline $\begin{array}{l}\text { Human Capital * } \\
\text { Information Tecnology }> \\
\text { HR Performance }\end{array}$ & 1,066250 & 1,030481 & 0,582517 & 0,582517 & 1,830419 \\
\hline $\begin{array}{l}\text { Social Capital * } \\
\text { Information Technology } \\
->\text { HR Performance }\end{array}$ & 0,909124 & 0,927964 & 0,526458 & 0,526458 & 1,726869 \\
\hline
\end{tabular}

Source: Primary Data Process, 2018

\section{DISCUSSION}

Based on the test of the relationship between constructs in Table 5, the hypothesis proposed in this study can be explained as follows:

\section{The Effect of Human Capital on HR Performance}

The first hypothesis proposed in this study is "The higher human capital, the performance of human resources increases". In Table 4.14 shows that the relationship between Human Capital and HR Performance is a significant positive effect because the statistical value is greater than t table (statistical 3.051936>t table 1.66) at the significance level of 5\%. Thus, the first hypothesis which states "The higher human capital, the performance of human resources increases" can be accepted.

The results of hypothesis testing prove that Human Capital (with indicators of skills change, creativity, and becomes the best) can significantly improve HR Performance (with indicators of quality of communication, decision making, work quantity, and quality of work) in the Technical Implementation Units (UPTs) of Monitor Radio Frequency Spectrum Class I Semarang and Yogyakarta. It means that to encourage the improvement of HR performance, Technical Implementation Units (UPTs) of Monitor Radio Frequency Spectrum Class I Semarang and Yogyakarta need to improve the quality of human capital so that the skills in carrying out work will be continuously.

Human capital is considered as one of the most important assets for the organization, and differences in the level of human capital between organizations will result in differences in competitive advantage. The success of creating effective human capital is directly able to influence positive performance outcomes. Buller and McEvoy (2012) found that core employees were valuable and unique (that is, those with specific knowledge, skills, and abilities) were positively related to organizational competitiveness and efficiency. Likewise, Samagaio and Rodrigues (2016) find that human capital is strongly related to performance. Organizations are able to achieve goals and improve maximum work performance through the practice of human resources intended to improve employee competency.

Human capital is an important component in achieving high performance, especially when investing in human resources is focused on knowledge and skills rather than focusing on the level of education (Staniewski, 2016). Organizations whose human resources have unique knowledge will achieve greater success and high-income productivity. The results of this study 
are consistent with the findings of Augusto Felício et al. (2014); McDowell et al. (2018); Ruiz et al. (2017); Subramony et al. (2018) that human capital has a significant positive effect on employee performance.

\section{The Effect of Human Capital on Social Capital}

The second hypothesis proposed in this study is "The higher the human capital, the social capital increases". Based on Table 5 shows that the relationship between Human Capital and Social Capital is a significant positive effect because the statistical value is greater than $\mathrm{t}$ table $\left(\mathrm{t}_{\text {statistics }} 29.014131>\mathrm{t}_{\text {tabel }}\right.$ 1.66) at the significance level of 5\%. Thus, the second hypothesis which states "The higher the human capital, the social capital increases" can be accepted.

The results of hypothesis testing prove that Human Capital (with indicators of skills change, creativity, and becomes the best) can significantly increase Social Capital (with indicators of trust, reciprocal and social interaction) in the Technical Implementation Units (UPTs) of Monitor Radio Frequency Spectrum Class I Semarang and Yogyakarta. This means that changes in skills with the ability and accuracy in completing work appropriately can encourage trust and social interaction of employees in the Technical Implementation Units (UPTs) of Monitor Radio Frequency Spectrum Class I Semarang and Yogyakarta.

Human capital is directly related to social capital. Formal knowledge obtained by employees at the individual level seems to be significantly related to social capital. This greatly supports professionalism in work, which is related to employee capacity, so that they contribute optimally to the organization. This finding verifies that cognitive abilities and work experience are factors that are directly related to social capital, namely involvement and personal relationships. In this case, personal relationships greatly affect the status and social relations of employees. In turn, the situation of social status will greatly affect the social attachments that arise mainly from family support. This study provides empirical evidence on the importance of human capital and social capital, which emphasizes individual employees to identify opportunities and take advantage of opportunities to create superior organizations (Zhou et al., 2017).

The results of this study are in line with the findings of Augusto Felício et al. (2014); Goxe (2010); Liu (2017) which proves that human capital has a significant effect on social capital.

\section{The Effect of Social Capital on HR Performance}

The third hypothesis proposed in this study is "The higher social capital, the performance of human resources increases". Based on the results of path coefficient analysis in Table 5 shows that the relationship between Social Capital and HR Performance is a significant positive effect because the statistical value is greater than $t$ table $\left(\mathrm{t}_{\text {statistics }}\right.$ 7.760937> table 1.66) at the $5 \%$ significance level. Thus, the third hypothesis in this study which states "The higher the social capital, the performance of human resources increases" can be accepted.

Hypothesis testing results prove that Social Capital (with indicators of trust, reciprocal, and social interaction can significantly improve HR Performance (with indicators of the quality of communication, decision making, quantity of work, and quality of work) in the Implementing 
Technical Implementation Units (UPT) of Monitor Radio Frequency Spectrum Class I. This means that to encourage and realize superior HR performance improvements, it is necessary to build trust and social interaction between employees in adjusting to job changes.

The core perspective of social capital theory is that network relationship is the exchange of valuable resources, information flows, and knowledge transfer for members involved in the network (Kim et al., 2016). Social capital is seen as a number of actual and potential resources that are deeply embedded, available and derived from a network of relationships that are owned by individuals or societies. Information and communication sharing that occurs through social networks, both internally and externally, is often considered important to integrate and synthesize knowledge generated by employees (McDowell et al., 2018).

Achieving competitive advantage is the result of social capital accumulated in the exchange of tacit and explicit knowledge through social networks in organizations (Smith and Coakes, 2012). The development of social capital requires great attention that enables interaction, facilitates the development of relationships, and encourages collaboration between employees. Social capital, as an intangible resource, is a very difficult thing for competitors to imitate. Therefore, social capital creates value for the organization through communication and assimilation of knowledge at the individual level, which helps organizations achieve and maintain a competitive advantage.

The results of this study are in line with the findings of Fonti and Maoret (2016); Islam et al. (2018); Liu (2017); Subramony et al. (2018) which proves that social capital improves employee performance.

\section{The Effect of Information Technology in Moderating the Relationship Between Social Capital and HR Performance}

The fourth hypothesis proposed in this study is "Information technology moderates the relationship between social capital and human resource performance". Based on Table 6, it shows that the interaction variable between Information Technology and Social Capital on HR Performance is significant because the statistical value is greater than $t$ table $\left(t_{\text {statistics }} 1.726869>\right.$ $\mathrm{t}$ table 1.66) at the significance level of 5\%. Thus, the fourth hypothesis proposed in this study namely "Information technology moderates the relationship between social capital and human resource performance" is accepted.

The results of hypothesis testing prove that Information Technology (with indicators of adequate data and information management services, connectivity, reliability, and availability of good communication networks, quality information technology applications and services, and information technology management services connected to other business units) can moderate or strengthen the relationship between Social Capital (with indicators of trust, reciprocal, and social interaction) on HR Performance (with indicators of quality communication, decision making, quantity of work, and quality of work) in the Technical Implementation Units (UPT) of Monitor Radio Frequency Spectrum Class I Semarang and Yogyakarta. This means that with the integration of an adequate information technology system, it will encourage the desire of employees to carry out social interactions, which in turn increases the ability to complete work in a timely manner. 
Information technology that is always changing causes organizations to always face intense competition. For most organizations, strong technological capabilities will be the main competitiveness factor in the future. Technology-oriented organizations always try to carry out the process of developing new technologies so they can produce creative problem-solving abilities and versatile ways of thinking.

By adopting information technology capabilities, organizational efficiency and competitive advantage can be improved. In addition, rapid learning is seen as the key to success in the organization and learning at all levels becomes very important for the survival of the organization. Therefore, organizations must have the ability to learn to adjust and deal with changes in the work environment.

Integration of interpersonal social networks especially through information technology (such as online communication tools) can lead to greater resources or perceived performance benefits. Ewart and Snowden (2012) show that computer media can play an important role in social capital processes. Individuals can get social support from others during difficult times or obtain friendships when participating in social activities. More significantly, they can obtain prospects for new employment opportunities or obtain financial support when needed. Therefore, diverse social networks provide more communicative opportunities and social interaction, which can lead to a greater sense of belonging, thus it supports the realization of performance in the organization.

The result results is in line with Wadhwa et al. (2017) that stated that social capital support the increase of information technology, that in turn, it affects the employee performance.

\section{The Effect of Information Technology in Moderating the Relationship Between Human Capital and HR Performance}

The fifth hypothesis proposed in this study is "Information technology moderates the relationship between human capital and the human resources performance ". Based on Table 6, it shows that the Information Technology and Human Capital variables on HR Performance are significant because the statistical value is greater than $\mathrm{t}$ table $\left(\mathrm{t}_{\text {statistics }} 1.830419>\mathrm{t}\right.$ table 1.66) at the $5 \%$ significance level. Thus, the fifth hypothesis which states "Information technology moderates the relationship between human capital and the performance of human resources" is accepted.

The results of hypothesis testing prove that Information Technology (with indicators of adequate data and information management services, connectivity, reliability, and availability of good communication networks, quality information technology applications and services, and information technology management services connected to other business units) can moderate or strengthen the relationship between Human Capital (with indicators of change in skills, creativity, and becomes the best) on HR Performance (with indicators of communication quality, decision making, work quantity, and quality of work) in Technical Implementation Units (UPT) of Monitor Radio Frequency Spectrum Class I Semarang and Yogyakarta.

Information technology creates profits by exploiting pre-existing human capital, so that it complements each other. The use of sophisticated information technology in organizations generally always outperforms other organizations that are less sophisticated in using information 
technology. By combining information technology and human capital, it will create optimal performance.

The quality of human capital is one of the most important things in improving organizational competitiveness. Resources related to human capital owned by individuals cannot be replaced by machines because they are related to the knowledge, experience, competence, and creativity of individuals in the organization. Effective provision of human capital can be a tool used to make decisions about budget allocation, recruitment, staff training and performance improvement (Kostagiolas et al., 2011).

The results of this study are in line with the findings of Wadhwa et al. (2017) that human capital encourages the improvement of information technology, which in turn effects employee performance. Thus, it can be concluded that the quality of human capital is very important for organizations that have high technology to maintain a competitive advantage in a knowledgeable economic era.

\section{CONCLUSION}

In general, this study concluded that the performance of Human Resources can be strengthened and improved through Human Capital, Social Capital, and Information Technology. Future research needs to include important indicators (critical indicators) from Human Capital, Social Capital, Information Technology, and HR Performance to build a more complete research framework. Future research needs to add other variables that are thought to be able to improve HR performance, such as passion for work, work discretion, employeefriendly culture, tolerance for risk-taking, allocation of free time, and altruism.

\section{REFERENCES}

Augusto Felício, J., Couto, E., \& Caiado, J. (2014). Human capital, social capital and organizational performance. Management Decision, 52(2), 350-364.

Bharadwaj, A. S. (2000). A resource-based perspective on information technology capability and firm performance: an empirical investigation. MIS quarterly, 169-196.

Buller, P.F., \& McEvoy, G. M. (2012). Strategy, human resource management and performance: Sharpening line of sight. Human resource management review, 22(1), 43-56.

Burt, R. S. (2009). Structural holes: The social structure of competition: Harvard university press.

Ewart, J., \& Snowden, C. (2012). The media's role in social inclusion and exclusion. Media International Australia, 142(1), 61-63.

Fonti, F., \& Maoret, M. (2016). The direct and indirect effects of core and peripheral social capital on organizational performance. Strategic Management Journal, 37(8), 17651786.

Galbraith, J. R. (2012). The evolution of enterprise organization designs. Journal of Organization Design, 1(2), 1-13. 
Gheysari, H., Rasli, A., Roghanian, P., \& Jebur, H. (2012). The role of information technology infrastructure capability (ITIC) in management. International Journal of Fundamental Psychology \& Social Sciences, 2(2), 36-40.

Goxe, F. (2010). Human and social capital interplay among internationalizing SMEs. Journal of Knowledge-based Innovation in China, 2(1), 73-88.

Islam, M. M., Habes, E. M., \& Alam, M. M. (2018). The usage and social capital of mobile phones and their effect on the performance of microenterprise: An empirical study. Technological Forecasting and Social Change, 132, 156-164.

Kim, M. J., Lee, C.-K., \& Bonn, M. (2016). The effect of social capital and altruism on seniors' revisit intention to social network sites for tourism-related purposes. Tourism Management, 53, 96-107.

Kmieciak, R., Michna, A., \& Meczynska, A. (2012). Innovativeness, empowerment and IT capability: evidence from SMEs. Industrial Management \& Data Systems, 112(5), 707728.

Kostagiolas, P. A., \& Asonitis, S. (2011). Managing intellectual capital in libraries and information services Advances in librarianship (pp. 31-50): Emerald Group Publishing Limited.

Liu, C.-H. (2017). The relationships among intellectual capital, social capital, and performanceThe moderating role of business ties and environmental uncertainty. Tourism Management, 61, 553-561.

McDowell, W. C., Peake, W. O., Coder, L., \& Harris, M. L. (2018). Building small firm performance through intellectual capital development: Exploring innovation as the "black box". Journal of business research, 88, 321-327.

Mitić, S., Nikolić, M., Jankov, J., Vukonjanski, J., \& Terek, E. (2017). The impact of information technologies on communication satisfaction and organizational learning in companies in Serbia. Computers in Human Behavior, 76, 87-101.

Pang, H. (2018). How does time spent on WeChat bolster subjective well-being through social integration and social capital? Telematics and Informatics.

Putnam, R. D. (2012). Bowling alone: America's declining social capital Culture and politics (pp. 223-234): Springer.

Samagaio, A., \& Rodrigues, R. (2016). Human capital and performance in young audit firms. Journal of business research, 69(11), 5354-5359.

Smith, P., \& Coakes, E. (2012). Exploiting KM in Support of Innovation and Change Organizational Learning and Knowledge: Concepts, Methodologies, Tools and Applications (pp. 197-207): IGI Global.

Staniewski, M. W. (2016). The contribution of business experience and knowledge to successful entrepreneurship. Journal of business research, 69(11), 5147-5152. 
Subramony, M., Segers, J., Chadwick, C., \& Shyamsunder, A. (2018). Leadership development practice bundles and organizational performance: The mediating role of human capital and social capital. Journal of business research, 83, 120-129.

Wadhwa, P., McCormick, M., \& Musteen, M. (2017). Technological innovation among internationality active SMEs in the Czech economy: Role of human and social capital of CEO. European Business Review, 29(2), 164-180.

Zhou, L., Chan, E., \& Song, H. (2017). Social capital and entrepreneurial mobility in earlystage tourism development: A case from rural China. Tourism Management, 63, 338350. 